\title{
Strategy for Improving Quality of Service in Management of Library in Tadulako University
}

\author{
Prita Andarbeni ${ }^{1}$, Iwan Satibi ${ }^{2}$, Ummu Salamah ${ }^{3}$ \\ ${ }^{1}$ Universitas Tadulako Palu, Indonesia \\ ${ }^{2,3}$ Universitas Pasundan Bandung, Indonesia \\ Email: pritaaza.130469@gmail.com
}

\begin{abstract}
The main problem in research is that the quality of library management services at the University of Tadulako is not yet optimal. This study aims to study and analyze the library service quality strategy carried out by library officials at Tadulako University. This research was conducted using a mixed method, through two approaches namely quantitative and qualitative (mix method). The data collection is done through questionnaires, participant observation, and interviews. The results of the study found that the quality of library services is largely determined by the completeness of facilities and infrastructure, reliability, responsiveness of officers, the ease of service processes and security guarantees while in the library building. This study concludes that in order to improve the quality of library services, it is needed a strategy to improve the quality of services based on information technology (IT). The strategy that needs to be done to improve the quality of library services is the service diversification strategy, which is a strategy that focuses on optimizing the use of force to reduce threats.
\end{abstract}

Keywords: Service Quality, Information Technology, Diversification Strategy.

\section{A. INTRODUCTION}

The presence of libraries for tertiary institutions is one of the most important supporting factors to support reference services for the academic community, especially students and lecturers. This is in line with the main mission of the library which in essence is providing information services which include: reference services, information retrieval and information retrieval services, circulation services, bibliographic consultation, provision of comfortable reading / learning facilities. In addition, libraries must also provide user education services to improve the insight and skills of users in using library services, collections, and supporting facilities, specifically the use of information and communication technology (Puspa, 2016).

The phenomenon that appears shows that the quality of library services in the University of Tadulako is not optimal, so that it has implications for the satisfaction of the visitors. Strengthening these phenomena is reflected in the problem map as shown in the table below: 
Table 1 Library Service Issues at Tadulako University

\begin{tabular}{|l|l|}
\hline \multicolumn{1}{|c|}{ Problem } & \multicolumn{1}{c|}{ Reality } \\
\hline $\begin{array}{l}\text { Library service facilities include BNI Cor- } \\
\text { ner, OPAC, E-journal, Proceedings, Scien- } \\
\text { tific Work and magazine series }\end{array}$ & $\begin{array}{l}\text { 1. the internet is sometimes slow } \\
\text { 2. electric often dies }\end{array}$ \\
\hline Physical collection is less interested & collection lacking updates \\
\hline The library building is less representative & $\begin{array}{l}\text { 1. Large collection room } \\
\text { 2. Lack of space to read } \\
\text { 3. Each service unit is separated from } \\
\text { one building to another }\end{array}$ \\
\hline
\end{tabular}

Source: Research Results, 2019

The above problems reinforce the argument that empirical library services at Tadulako University have not been optimally managed. Though higher education libraries have functions and objectives that are interrelated and aim to provide good services in the library.

With the existence of services in the objectives of the university library will make users will be easy to take advantage of library functions. Library library users consist of various groups such as students, lecturers and university community. The library also provides library education services that aim to provide knowledge to users in making optimal use of the library. The existence of good services by the library will provide an attraction to the library for users (Zaharani \& Primadesi, 2014).

Therefore, library managers must strive for optimal quality of library services. In other words, librarians must be able to display excellent service performance, so that they can meet the needs of visitors (users) according to their expectations (Kalsum, 2016).

The quality of library services is a description of how well the product or service (service), especially how well in terms of adjusting and meeting the needs of its visitors and free from things that cause library dissatisfaction (Damayanti, 2006). The visitors are library users, namely individuals, groups of people, communities, or institutions that utilize library service facilities (Zaharani \& Primadesi, 2014).

Substantively, the quality and value (value) of a library is measured by an indicator of the quantity, namely: the number of collections, budgets, expenditures, and staff that are input to assessing the potential of the library in meeting the needs of users (Nurkertamanda \& Wirawan, 2009). That's why Nasution (2004) revealed several factors to improve service quality that need to be considered by service providers in this case the library is managing user expectations, managing evidence of service quality, developing a quality culture, developing a service quality information system, identifying key determinants of service quality, major determinants of service quality, educating consumers and following up on services, as well as to create quality automatically. 
Indeed, quality is not the result of a combination of accidental factors, therefore quality must be defined, designed, planned, and implemented appropriately, where customer satisfaction can create customer loyalty or loyalty to institutions that provide satisfying quality (Tjiptono \& Diana, 2003). The development of current information always demands the existence of information provider institutions that are able to improve information service systems quickly, precisely and able to fulfill information for users. Therefore the government as a service provider is required to improve public services in the information and education services sector.

As an agency that provides information services, libraries can provide services to users, including: 1) locker services; 2) circulation services; 3) reference services; 4) information retrieval services; 5 ) the latest collection information service; 7) reading room service; 8) photocopying services; 9) workstation and multimedia services (Rahayuningsih, 2007). The characteristics of quality library services can be seen from the collection which includes the quantity associated with the large number of collections owned by the library and quality relating to the quality, latestness, completeness of the collection. Furthermore, facilities which include completeness, involve the scope of services and the availability of supporting facilities and other complementary services. In addition to completeness there is also the convenience of obtaining services related to location, room, instructions, availability of information, cleanliness and others. The next characteristic is human resources, which includes the courtesy and friendliness of officers providing services, especially for officers who interact directly with users. Another characteristic is the responsibility in serving library users. Empathy, fair and just in solving problems and handling complaints from users. The professionalism of the library staff in the library service section is reflected in the person who is SMARTminded, that is Ready to secure services, Fun and interesting, Enthusiastic/proud of, Friendly and respectful of service users, steadfast amid difficulties (Rahayuningsih, 2013).

To measure the quality of library services based on servqual dimensions which include; (1) tangible, namely the quality of services in the form of office physical facilities, computerized administration, waiting rooms, information places; (2) reliability, namely the ability and reliability to provide trusted services; (3) responsiveness, namely the ability to help and provide services quickly and appropriately, and be responsive to consumer desires; (4) assurance, which is the ability and understanding and courtesy of employees in convincing consumer trust; and (5) empathy, which is an assertive but attentive attitude from employees towards consumers (Zeithaml et al., 1990).

\section{B. METHODS}

The research method used is a mixed method, which combines two approaches namely quantitative and qualitative. Combined research method or mix method is a research method that combines or combines quantitative methods and qualitative meth- 
ods to be used together in a research activity in order to obtain more comprehensive, valid, reliable and objective data. While the mixed model used is sequential explanatory, namely research design which is characterized by collecting and analyzing quantitative data in the first stage, and followed by the collection and analysis of qualitative data in the second stage, in order to strengthen the results of quantitative research conducted in the first stage (Sugiyono, 2012).

\section{RESULTS AND DISCUSSION}

\section{Service Quality Servqual Model in Library Management}

The results showed that the services provided by the library at Tadulako University in general can be carried out in accordance with applicable systems and procedures. However, qualitatively, the service has not been fully able to provide satisfaction in accordance with the expectations of visitors (users). According to the Indonesian National Standard (SNI) the library must provide space of at least $0.5 \mathrm{~m} 2$ for each student, with the use of a $45 \%$ collection area consisting of book collection space, multimedia room, scientific magazine collection room. While the library staff area of $25 \%$ consists of processing rooms, binding rooms, meeting rooms, newly received book storage rooms, kitchens and toilets.

The results of the study also revealed that to improve the quality of human resources in the library environment needs to be done in a systematic, measurable and sustainable manner. This is considered very important to be done so as to create a balance between the needs of human resources with the demands and progress of the library.

In line with the above context, the resources of the library apparatus are translated as all apparatus involved in the library whose job is to strive towards the realization of the library's goals. Therefore the management of library apparatus resources means the preparation and implementation of a coordinated plan to ensure that the existing library apparatus resources can be utilized as well as possible to achieve the library's goals (Hermawan \& Zen, 2006).

The results of this study also show that operationally the Tadulako University library needs to pay attention to five dimensions of service quality, namely Tangible (Physical Evidence). In this context, the library still needs an increase in physical facilities and adequate infrastructure to support the quality of library services. This is in line with one of the service principles stated in the Decree of the Minister of Administrative Reform and Bureaucratic Reform No. 14 of 2017, namely the availability of work facilities and infrastructure by public service providers.

The next dimension is reliability or reliability, namely the ability of librarians to provide services quickly, accurately and satisfactorily (Masruri, 2004). Empirical facts show that one form of good library service is the creation of library services that are fast and precise. In this context, internet access needed to serve visitors (visitors) is already 
available. However, the quality of the internet used is not yet fully adequate. This is reflected in the presence of complaints from visitors related to internet networks that are slow and difficult to access, especially when visitors or visitors are busy using internet network access;

In terms of responsiveness or responsiveness, it was found that library staff were judged to be able to assist and serve the visitors or visitors quickly and accurately. In addition, the level of responsiveness of the officers was also considered to be quite good, in the sense that they had responded to requests related to the information needs of users. The importance of responsiveness in library services is also revealed from the results of Harmoko's research (2017), which concludes that the responsiveness of library staff will greatly determine the level of quality of library services which will then affect the satisfaction of users.

The results of the study also illustrate that from the Assurance side, it was found that the Tadulako University Library in general was considered to be able to guarantee the ease of requirements in making membership cards or other important letters needed by users. This reflects that the library administration administratively has displayed good service performance, so that it is considered capable of meeting the personal needs of visitors (users). In this regard Rodin (2015) suggests that personal needs (self-needs) are the expectations of customers that arise because of their characteristics and needs.

Emphaty is the ability to give sincere and individual or personal attention given to users by trying to understand the wishes of users (Amal, 2015). From this empathy point, it is found that in general library staff are considered to have paid enough attention to visitors (pemustaka). In other words, the library staff are considered to have been able to understand the desires of visitors.

\section{Strategy to Improve the Quality of Library Services}

In the college environment, the library is a place where students and lecturers can obtain information and study independently in order to improve their quality. As an information center, the library is not only limited to buildings and books. Modern libraries have duties and functions to search, collect, organize, document and present information to users, both in printed form and in electronic form (Rodin, 2015). Therefore, libraries are required to be able to display their service performance in accordance with the demands and needs of users. In other words, the library manager must always strive to improve the quality of service in accordance with the demands and needs of visitors (users).

In line with the above context, the results of the study found that to improve the quality of service, a strategy is needed in managing the library at Tadulako University. This is in line with the results of research Novianti et.all (2017) whose essence explains that the position of the library not only serves to provide information and references on- 
ly, but also requires the comfort of physical facilities, adequate information technology, and the attitude of professional managers (Novianti, 2015).

Analysis of the strategy carried out to explain the improvement of service quality in library management is done by using a SWOT analysis. This analysis is carried out to determine the internal environmental factors, which include; strength (strength), weakness (weakness), and external environmental factors, which include; threats (threats) and what are the opportunities (opportunities), in the management of the library. The results of the internal environmental factor analysis of the Tadulako University library, can be seen in the table below:

\section{Table 2 Internal Factor Evalution Matrix}

\begin{tabular}{|c|c|c|c|c|}
\hline No & Internal Factors & Weight & Rating & $\begin{array}{l}\text { Weight } \times \text { Rat- } \\
\text { ing }\end{array}$ \\
\hline \multicolumn{5}{|c|}{ Strength } \\
\hline 1 & Service System & 0,4 & 4 & 1,6 \\
\hline 2 & Facilities and infrastructure & 0,2 & 3 & 0,6 \\
\hline 3 & Human Resources & 0,4 & 4 & 1,6 \\
\hline \multicolumn{2}{|r|}{$\begin{array}{ll}\text { Total } \\
\end{array}$} & 1 & & 3,8 \\
\hline \multicolumn{5}{|c|}{ Weakness } \\
\hline 1 & Collection & 0,35 & 2 & 0,7 \\
\hline 2 & Budget Limitations & 0,45 & 1 & 0,45 \\
\hline 3 & Condition of Library Building & 0,2 & 2 & 0,4 \\
\hline \multicolumn{2}{|r|}{ Total } & 1 & & 1,55 \\
\hline
\end{tabular}

Source: Research Results, 2019

Then the results of the analysis of external environmental factors, which include threats and opportunities in library management can be seen in the table below:

Table 3 External Factor Evaluation Matrix

\begin{tabular}{|c|c|c|c|c|}
\hline No & External Factors & Weight & Rating & Weight $x$ Rating \\
\hline \multicolumn{5}{|c|}{ Opportunity } \\
\hline 1 & $\begin{array}{l}\text { Development Cooperation } \\
\text { Library with other PTN and PTS }\end{array}$ & 0,30 & 2 & 0,60 \\
\hline 2 & $\begin{array}{l}\text { The development of IT and commu- } \\
\text { nication }\end{array}$ & 0,32 & 2 & 0,64 \\
\hline 3 & $\begin{array}{l}\text { The development of study programs } \\
\text { has encouraged an increase in the } \\
\text { number of related collections }\end{array}$ & 0,23 & 2 & 0,46 \\
\hline 4 & University Policy & 0,15 & 2 & 0,30 \\
\hline \multicolumn{2}{|r|}{ Total } & 1 & & 2,00 \\
\hline \multicolumn{5}{|c|}{ Threat } \\
\hline 1 & The emergence of new information & 0,55 & 3 & 1,65 \\
\hline
\end{tabular}




\begin{tabular}{|c|l|c|c|c|}
\hline \multicolumn{1}{|c|}{ centers } & & & \\
\hline 2 & $\begin{array}{l}\text { Many opportunities to attend the } \\
\text { Library Training }\end{array}$ & 0,45 & 2 & 0,90 \\
\hline \multicolumn{1}{|c|}{ Total } & $\mathbf{1}$ & & $\mathbf{2 , 5 5}$ \\
\hline
\end{tabular}

Source: Research Results, 2019

The above calculation results interpretatively can be explained in the SWOT analysis matrix table below:

Table 4 SWOT Analysis Matrix

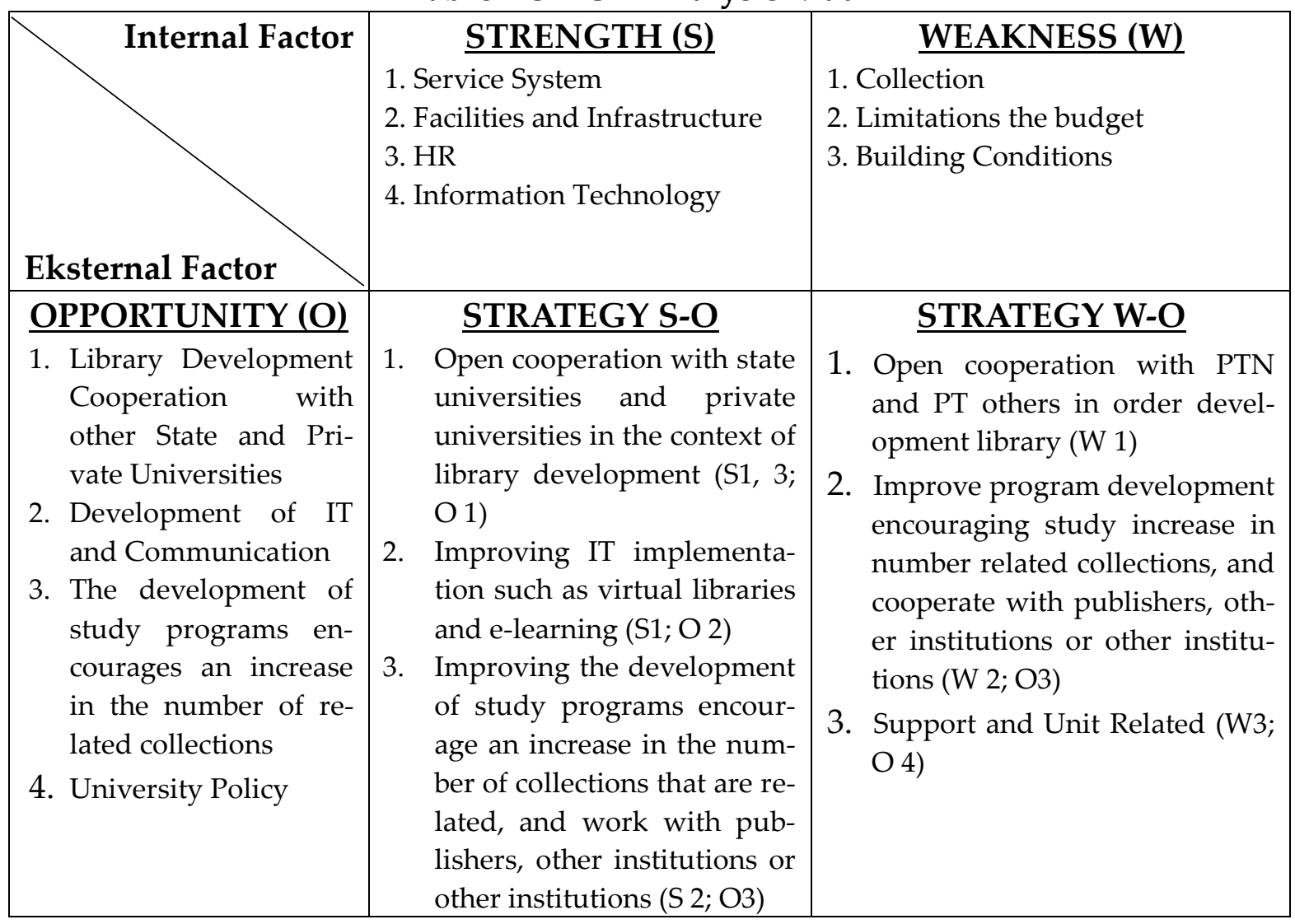

Source: Research Results, 2019

The above table illustrates that the strategies that need to be taken to improve the quality of library services at Tadulako University, include; The SO strategy (Strength opportunities) consists of: (1) opening cooperation with state universities and other private universities in order to develop library service quality; (2) improving IT implementation such as virtual libraries, e-learning. Internet network system is very influential on the progress of the library service system, so that with a maximum network system will be increasingly in demand by users in finding the information needed, (3) increasing the development of study programs encourage an increase in the number of related collections, both collaboration with publishers, agencies another or another institution. WO Strategy (Weakness Opportunity) The strategies undertaken: (1) open cooperation with state universities and other PTS in the framework of developing the quality of li- 
brary services; (2) increasing the development of the study program encourages an increase in the number of related collections, adjusted to the curriculum, courses and the need for collection of proposals from each department in each faculty by distributing a book catalog from the publisher and adapted to the needs of each faculty. Besides cooperating with other agencies or institutions; (3) support from the unit proposes a policy to the leadership of the university for the construction of a new library building in accordance with the rules and regulations that have been set. Strategy of ST (Strength Treats). This strategy includes: (1) improving library service systems that have been integrated with faculties; (2) increasing library human resource competition by providing opportunities to improve the quality of library human resources through training, seminars and other activities in the field of library science.

Visually the results of an analysis of strategies to improve the quality of library services at Tadulako University, can be seen in Figure 1 below:

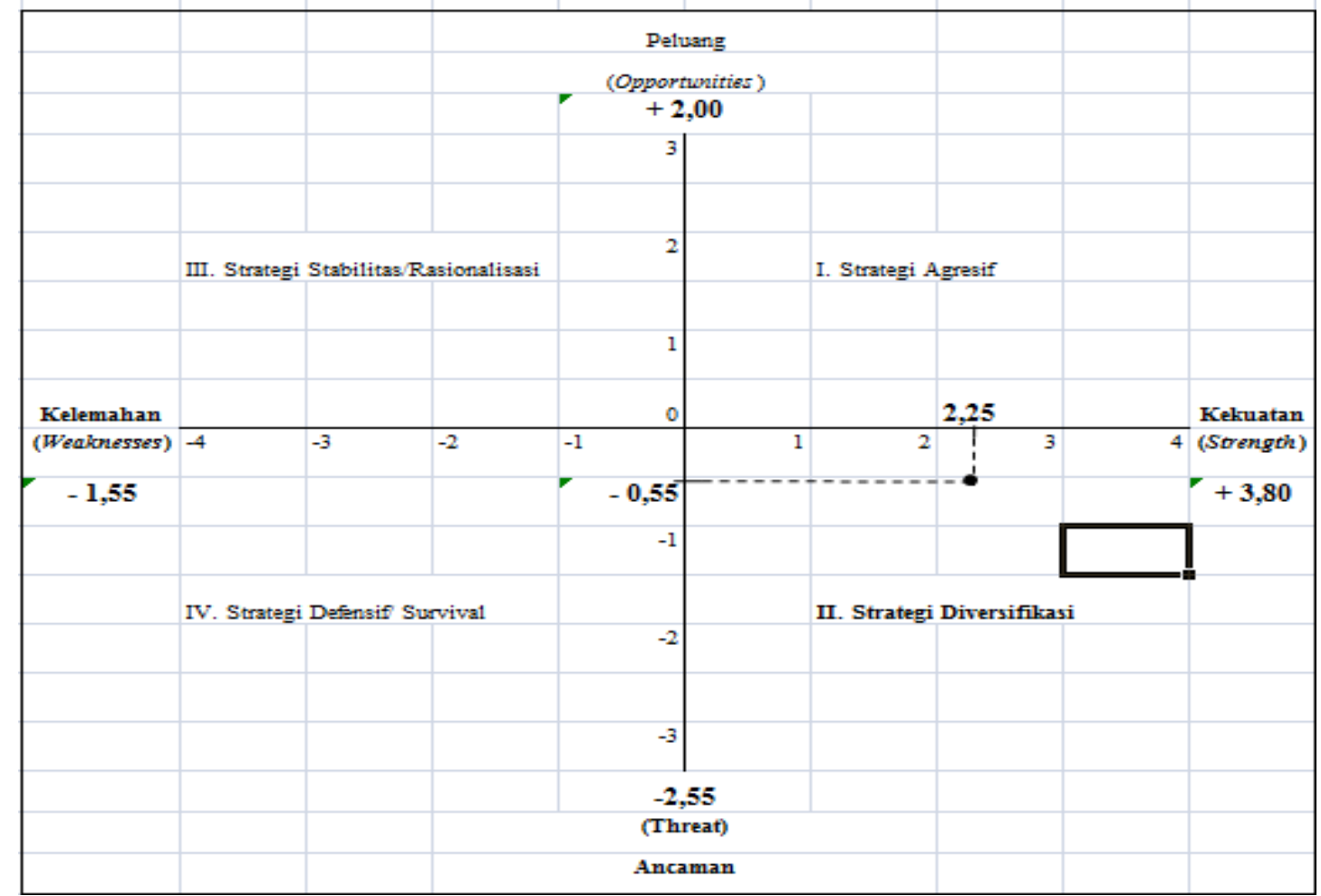

Image 1 Outstanding Strategy for Improving the Quality of Library Services

The table above shows that the results of the analysis of the calculation of Strength Weakness (S-W) obtained a figure of 2.25, while the results of the analysis of Opportunity Threat (O-T) obtained of -0.55 . Thus, the position of the analysis lies in quadrant II. This implies that the choice of strategy that needs to be done to improve the quality of library services is a service diversification strategy, which is a strategy that focuses on optimizing the use of force to reduce threats, because in the face of threats, Tadulako University library actually still has power. The strengths owned by the Tadu- 
lako University Library today include; the potential of human resources (librarians), building facilities, library facilities and information technology.

\section{CONCLUSION}

The results of the study concluded that empirically, improving the quality of library services at Tadulako University was determined by five dimensions, namely tangible, in the form of adequate office physical facilities, integrated computerized systems, comfortable waiting rooms, and information places; reliability, namely the ability and reliability of library staff to provide services; responsiveness, officers to assist and provide services quickly and accurately, and are responsive to the wishes of users; assurance, namely the ability and understanding and courtesy of employees in convincing users of trust; and empathy, namely the firm but attentive attitude of employees towards the visitors. The strategy that needs to be done to improve the quality of library services at Tadulako University, namely the service deversification strategy, which is a strategy that focuses on optimizing the use of force to reduce threats, because in the face of threats, Tadulako University library actually still has power.

\section{REFERENCES}

1. Amal, E. (2016). Analisis Pelayanan Perpustakaan Pada Kantor Perpustakaan Arsip Dan Dokumentasi Kabupaten Sigi. Katalogis, 4(4).

2. Damayanti, A. (2006). Evaluasi kualitas layanan CD-ROM di PUSTAKA dengan metode libqual+ tm (Doctoral dissertation, FIB-UI).

3. Harmoko, S. (2017). Analisis Tingkat Kepuasan Pemustaka terhadap Kualitas Layanan di Perpustakaan Politeknik Kesehatan Kementerian Kesehatan Yogyakarta. JIPI (Jurnal Ilmu Perpustakaan dan Informasi), 2(2), 164-188.

4. Hermawan, R., \& Zen, Z. (2006). Etika Kepustakawanan: Suatu Pendekatan terhadap profesi dan Kode Etik Pustakawan Indonesia. Jakarta: Sagung Seto.

5. Kalsum, U. (2016). Referensi sebagai layanan, referensi sebagai tempat: sebuah tinjauan terhadap layanan refernsi di perpustakaan perguruan tinggi. IQRA: Jurnal Ilmu Perpustakaan dan Informasi (e-Journal), 10(1), 132-146.

6. Masruri, A. (2004). Kualitas pelayanan perpustakaan (Studi kasus pada perpustakaan IAIN Sunan Kalijaga Yogyakarta). Berkala Ilmu Perpustakaan dan Informasi, 1(2), 4-12.

7. Nasution, M. N. (2004). Manajemen Mutu Terpadu (Total Quality Management). Jakarta: Ghalia Indonesia.

8. Novianti, H. T. (2015). Pengaruh Kualitas Pelayanan Terhadap Kepuasan Pemusataka (Studi pada Perpustakaan Umum dan Arsip Kota Malang). Jurnal Administrasi Publik, 3(5), 789-794. 
9. Nurkertamanda, D., \& Wirawan, P. (2009). Usulan Konsep Peningkatan Kepuasan Pengguna Perpustakaan dengan Menggunakan Metodologi LibQUAL+ ${ }^{\mathrm{TM}}$ dan Quality Function Deployment. J@ TI UNDIP, 4(2), 142-151.

10. Puspa, E. (2016). Analisis Kepuasan Pemustaka Terhadap Pelayanan Perpustakaan Pusat Penelitian dan Pengembangan Perikanan Budidaya. J. Pari, 2(2), 113-125.

11. Rahayuningsih, F. (2007). Pengelolaan Perpustakaan. Yogyakarta: Graha Ilmu.

12. Rahayuningsih, F. (2013). Analisis Kepuasan Pemustaka terhadap kualitas jasa layanan menggunakan metode Libqual. Vol11, (2).

13. Rodin, R. (2015). Urgensi kualitas pelayanan perpustakaan perguruan tinggi. $A l$ Kuttab: Jurnal Perpustakaan dan Informasi, 2(1), 1-20.

14. Sugiyono. (2012). Metodologi Penelitian Administrasi: Pendekatan Kuantitatif, Kualititaif dan RED. Bandung: Alfabeta.

15. Tjiptono, F., \& Diana, A. (2003). Total Quality Management. Yogyakarta: Andi.

16. Zaharani, R., \& Primadesi, Y. (2014). Pengaruh Layanan Perpustakaan Terhadap KKepuasan Pemustaka di Perpustakaan Universitas Negeri Padang. Ilmu Informasi Perpustakaan dan Kearsipan, 3(1), 152-158.

17. Zeithaml, V. A., Parasuraman, A., \& Berry, L. L. (1990). Delivering Quality of Service: Balancing Customer Perception and Expectation. New York: The Free Press. 